\title{
Department of Veterans Affairs compensation and medical care benefits accorded to veterans with major limb loss
}

\author{
Charles Maynard, PhD; ${ }^{1}$ Brad Flohr; ${ }^{2}$ Tony A. Guagliardo, MS; ${ }^{3}$ Chris H. Martin, MA; ${ }^{3}$ Lynne V. McFarland, \\ PhD; ${ }^{1}$ Jonathan D. Pruden, MPS; ${ }^{4}$ Gayle E. Reiber, MPH, PhD $^{{ }^{*}}$ \\ ${ }^{1}$ Health Services Research and Development, Department of Veterans Affairs (VA) Puget Sound Health Care System, \\ Seattle, WA; ${ }^{2} V A$, Veterans Benefits Administration, Central Office, Washington, DC; ${ }^{3} V A$, Veterans Health Administra- \\ tion, Central Office, Washington, DC; ${ }^{4}$ Wounded Warrior Project, Gainesville, FL
}

\begin{abstract}
Veterans injured in theaters of combat operations are eligible for benefits, including medical care and compensation. This article describes veterans with service-connected disability for major lower- and/or upper-limb loss resulting from combat-field-associated injuries sustained in the Vietnam war, Operation Desert Shield/Operation Desert Storm, and Operation Iraqi Freedom/Operation Enduring Freedom (OIF/OEF). Using the Department of Veterans Affairs (VA) Compensation and Pension Mini-Master file, we identified 2,690 veterans who in August 2007 received compensation for loss of one or more limbs. More than 97\% sustained their injuries in Vietnam; most were young men who served in the U.S. Army or Marine Corps. All but 5\% had at least 50\% combined serviceconnected disability and nearly half had a $100 \%$ rating. In addition to limb loss, one of the most prevalent compensable conditions was posttraumatic stress disorder, present in $46 \%$ of OIF/OEF and $20 \%$ of Vietnam veterans. Of these veterans, $82 \%$ visited VA outpatient clinics in 2007, although only $4 \%$ were hospitalized. A special obligation exists to those who have sustained serious injuries related to combat; this responsibility extends for the life of the servicemember and beyond to his or her spouse and dependents.
\end{abstract}

Key words: amputation, benefits, combat, limb loss, OIF/OEF, posttraumatic stress disorder, service-connected disability, VA, veterans, Vietnam war.

\section{INTRODUCTION}

Veterans injured in theaters of combat operations are eligible for an array of Federal benefits, including medical care and compensation in proportion to the severity of their injury. In the United States, long-term medical care for war injuries is the responsibility of the Department of Veterans Affairs (VA) Veterans Health Administration (VHA) [1]. This integrated healthcare system of more than 153 hospitals and clinics is charged with providing medical care for those who are discharged from the military, including those who are severely injured as a result of military service. The Veterans Benefits Administration (VBA) is responsible for administering the various benefits programs, including compensation; pension; education; vocational rehabilitation; home loans; life insurance; burial and memorial assistance; and dependents' benefits,

\footnotetext{
Abbreviations: $\mathrm{C} \& \mathrm{P}=$ Compensation and Pension, $\mathrm{DOD}=$ Department of Defense, OIF/OEF = Operation Iraqi Freedom/ Operation Enduring Freedom, PTSD = posttraumatic stress disorder, $\mathrm{TBI}=$ traumatic brain injury, $\mathrm{VA}=$ Department of Veterans Affairs, VBA = Veterans Benefits Administration, VHA = Veterans Health Administration.

* Address all correspondence to Gayle E. Reiber, MPH, PhD; 1100 Olive Way, Suite 1400, Seattle, WA 98101; 206-7642089; fax: 206-764-2935. Email: greiber@u.washington.edu DOI:10.1682/JRRD.2009.02.0016
} 
including dependency and indemnity compensation for surviving spouses and education and training for spouses and children [2-3]. Veterans with service-connected disability are entitled to these benefits, including, most importantly, medical care and compensation for serviceconnected disability. Resources for veterans with major limb loss are described elsewhere in this supplement (see Appendix 3, available online only).

Although considerable literature exists on compensation and use of VHA medical care for posttraumatic stress disorder (PTSD) [4-7], relatively little is known about compensation and healthcare utilization in veterans who have lost one or more limbs. The purpose of this article is to describe the characteristics of veterans with service-connected disability for lower- and/or upper-limb loss resulting from injuries in the combat theaters in the Vietnam war, Operation Desert Shield/Operation Desert Storm, and Operation Iraqi Freedom/Operation Enduring Freedom (OIF/OEF) and to indicate the compensation received and medical care benefits utilized by this distinct population of veterans.

\section{METHODS}

\section{Population}

Veterans who lost one or more limbs were identified from the VA Compensation and Pension (C\&P) MiniMaster file located in Austin, Texas. We used C\&P diagnosis codes to identify the location of the amputation and also determined whether the injury was combat-fieldassociated and in what conflict it occurred. The following C\&P diagnosis codes were used to identify the location of the limb lost: hand (5106), arm (5120-5122), forearm (5123, 5124), foot (5107), thigh (5160-5162), leg (51635166), or both limbs (5104-1508). This analysis included individuals receiving compensation in August 2007 and did not include deceased veterans who had received payments. These 2,690 individuals formed the sampling frame for the survey of wounded veterans for whom results are reported in this issue of the Journal of Rehabilitation Research and Development [8].

\section{Study Variables}

From the C\&P Mini-Master file, we determined period of service, sex, age at entry into the military, age as of 2007, branch of service, percentage service-connected disability, location of amputation, presence of other ser- vice-connected condition(s), and amount of monthly benefits. Compensation is a monthly payment for those veterans who are at least 10 percent disabled as a result of military service. Pensions are monthly payments for those who are wartime veterans with a limited income, permanently and totally disabled, or at least 65 years old. The monthly compensation costs quoted in our study combine both compensation and pension benefits. We also used the VA patient treatment and outpatient care files to determine whether veterans were hospitalized or received outpatient care in VA facilities during fiscal year 2007.

\section{RESULTS}

There were 2,531 veterans with combat-associated limb loss from the Vietnam war, 13 from Operation Desert Shield/Operation Desert Storm, and (as of April 2007) 146 from OIF/OEF. More than 97 percent of veterans with major combat-associated limb loss receiving care within the VHA were from the Vietnam war (Table 1). When they entered military service, Vietnam servicemembers were slightly younger (mean [ \pm standard deviation] age = $20 \pm 3$ years) than their counterparts from Operation Desert Shield/Operation Desert Storm (mean age $=21 \pm$ 4 years) or OIF/OEF (mean age $=22 \pm 4$ years), although veterans from all conflicts can be generally characterized as young men or women who served in the military. Most (65\%-92\%) were enlisted in the U.S. Army at the time of their amputation.

All but a small proportion (5\%) of Vietnam veterans had at least 50 percent combined service-connected disability, and nearly half had a 100 percent rating (which includes all service-connected conditions). While 74 to 85 percent of the limb losses were unilateral lower limbs, OIF/OEF veterans had a slightly higher proportion of unilateral upper-limb loss (22\%) compared with Operation Desert Shield/Operation Desert Storm (15\%) or Vietnam (12\%) veterans.

More than 94 percent of veterans from the three conflicts had more than one type of disability. In addition to disability due to major limb loss, one of the most prevalent compensable conditions was PTSD. Compensable PTSD was present in 20 percent of the Vietnam veterans and 15 percent of the Operation Desert Shield/Operation Desert Storm veterans but was higher (46\%) in the OIF/OEF veterans. Conditions related to anxiety/neurosis were less common (4\%-8\%) in the three conflict groups. Diabetes 
Table 1.

Demographic and disability characteristics of U.S. veterans with major traumatic limb loss by period of service.

\begin{tabular}{|c|c|c|c|}
\hline Characteristic & $\begin{array}{c}\text { Vietnam } \\
(n=2,531)\end{array}$ & $\begin{array}{l}\text { Desert Shield/Desert Storm } \\
\qquad(n=13)\end{array}$ & $\begin{array}{c}\text { OIF/OEF* } \\
(n=146)\end{array}$ \\
\hline \multicolumn{4}{|l|}{ Demographic } \\
\hline \multicolumn{4}{|l|}{ Age (yr, mean \pm SD) } \\
\hline At Entry into Service & $20 \pm 3$ & $21 \pm 4$ & $22 \pm 4$ \\
\hline In 2007 & $59 \pm 3$ & $46 \pm 12$ & $27 \pm 5$ \\
\hline Men (\%) & 100 & 100 & 99 \\
\hline Navy & 3 & 0 & 4 \\
\hline Marine Corps & 31 & 0 & 23 \\
\hline U.S. Public Health Service & $<1$ & 0 & 0 \\
\hline Air Force & 1 & 8 & 3 \\
\hline \multicolumn{4}{|c|}{ Combined Degree of Disability (\%) } \\
\hline \multicolumn{4}{|l|}{ Location of Amputation (\%) } \\
\hline Upper Limb & 12 & 15 & 22 \\
\hline Lower Limb & 85 & 77 & 74 \\
\hline Both Upper and Lower Limb & 3 & 8 & 4 \\
\hline \multicolumn{4}{|l|}{ Other Types of Disabilities (\%) } \\
\hline Posttraumatic Stress Disorder & 20 & 15 & 46 \\
\hline Anxiety/Neurosis & 4 & 8 & 5 \\
\hline Diabetes Mellitus & 7 & 8 & 0 \\
\hline
\end{tabular}

mellitus, which has been linked to Agent Orange exposure in Vietnam, occurred in 0 to 8 percent of veterans from the three conflict groups. Very few individuals had disability codes indicative of traumatic brain injury (TBI).

Among the most important benefits for combat-injured veterans is compensation, the amount of which is tied to the extent of disability. As seen in Table 2, veterans with 100 percent disability received 1.6 to 1.8 times higher monthly payments than did those with lesser disability in all three conflict groups. VHA outpatient healthcare utili- zation was high, ranging from 80 to 97 percent (Table 2). Most veterans from all conflicts had at least one outpatient visit in fiscal year 2007, and all but two OIF/OEF veterans with 100 percent service-connected disability had at least one outpatient visit. The percentage with hospitalization was much smaller, ranging from 0 to 11 percent, but was highest for OIF/OEF veterans with 100 percent serviceconnected disability. From the databases available to us at the time, we could not determine the frequency of other types of benefits received by these veterans.

Table 2.

Compensation and medical care received by U.S. veterans with major traumatic limb loss by period of service and extent (\%) of disability.

\begin{tabular}{|c|c|c|c|c|c|c|}
\hline \multirow[b]{2}{*}{$\begin{array}{l}\text { Type of Compensation/ } \\
\text { Pension/Benefit }\end{array}$} & \multicolumn{2}{|c|}{ Vietnam } & \multicolumn{2}{|c|}{ Desert Shield/Desert Storm } & \multicolumn{2}{|c|}{ OIF/OEF } \\
\hline & $\begin{array}{c}0 \%-99 \% \\
(n=1,335)\end{array}$ & $\begin{array}{c}100 \% \\
(n=1,196)\end{array}$ & $\begin{array}{c}0 \%-99 \% \\
(n=5)\end{array}$ & $\begin{array}{l}100 \% \\
(n=8)\end{array}$ & $\begin{array}{c}0 \%-99 \% \\
(n=74)\end{array}$ & $\begin{array}{c}100 \% \\
(n=72)\end{array}$ \\
\hline Monthly Compensation 2007* & $1,880 \pm 798$ & $3,399 \pm 970$ & $1,916 \pm 657$ & $3,061 \pm 433$ & $1,786 \pm 649$ & $3,186 \pm 882$ \\
\hline VA Hospital Care in FY2007 (\%) & 4 & 7 & 0 & 0 & 1 & 11 \\
\hline
\end{tabular}


JRRD, Volume 47, Number 4, 2010

\section{DISCUSSION}

Vietnam, Operation Desert Shield/Operation Desert Storm, and OIF/OEF veterans with combat-associated major limb loss had similar demographic characteristics, degrees of disability, and levels of limb loss, except for more unilateral upper-limb loss in OIF/OEF veterans. These individuals, who were mostly young enlisted men serving in the U.S. Army or Marine Corps [8], receive monthly compensation and healthcare benefits from VA. Nearly half of veterans with combat-associated major limb loss receive 100 percent service-connected disability compensation.

In addition to compensation, VA provides eligible veterans a standardized and comprehensive medical benefits package [2]. For veterans who establish service connection for injury or disease, this medical benefits package is provided at little or no cost. Veterans with a rating of 100 percent service-connected disability are provided cost-free medical care, including medications for treatment of any disability. Other services provided to these veterans include dental, prosthetics, hearing aids, eye glasses, and institutional nursing home care. Veterans rated at least 50 percent but less than 100 percent are also eligible for similar services. An exception is dental care, which is generally limited to those specifically rated for a dental condition, or as noted above, those with a 100 percent service connection.

It was remarkable that almost half of OIF/OEF veterans had compensable PTSD. The presence of PTSD was lower in Vietnam veterans, but this may be due to the fact that the diagnosis of PTSD was not added to the American Psychiatric Association's Diagnostic and Statistical Manual of Mental Disorders until 1980 [9]. The finding that most individuals had multiple disabilities raises questions about coordination of care and where veterans receive their medical care. Because the VA databases used in this study did not contain healthcare utilization from other providers, our study is limited to care provided by VHA. Department of Defense (DOD) and civilian medical care were likely also used.

Some veterans with limb loss possibly experienced TBI, which occurs when a sudden trauma causes damage to the brain. Only recently has assessment of the prevalence of TBI been possible because of the development of a standard screening tool and definition [10]. Because of this, the documentation of TBI was just beginning in
2007, so there are no reliable estimates of TBI in previous conflicts.

A first limitation of this study is its reliance on crosssectional information on living beneficiaries in 2007. Historical data were not available to infer the likelihood of survival and the total lifetime benefits and compensation that will be utilized by these wounded individuals. However, if Vietnam veterans provide any indication, Operation Desert Shield/Operation Desert Storm and OIF/OEF veterans will likely survive well into their $60 \mathrm{~s}$ and $70 \mathrm{~s}$ [11]. Another limitation is that OIF/OEF veterans in this study represent only 25 percent of all OIF/OEF personnel who experienced major limb loss. Information provided by DOD indicated that as of 2007, more than 600 OIF/ OEF individuals had major limb loss. Some still may have been in rehabilitation, in the process of transferring to VA, or on Active Duty. Also, some may have received disability benefits from one of the branches of the Armed Forces, although this is unlikely given the more comprehensive benefit package offered by VA.

Administrative data also have inherent limitations. Information about whether the injury was combat-related, in which conflict it occurred, and which limb or limbs were lost is subject to error. In several cases after survey data were collected, we found that misclassification had occurred with respect to one or more of these items. Without the C\&P Mini-Master file, however, identifying veterans who suffered these devastating injuries would have been very difficult. Furthermore, information to track the timeliness and efficacy of the review process was not available, so we could not evaluate questions about backlog, timeliness of review, other types of benefits, or veteran satisfaction with the review process.

Concerns exist about the backlog of applications for disability benefits and the length of the evaluation process, despite efforts to improve timeliness [12]. Current workload reports on C\&P claims are available on the Internet [13], and recommendations for changing the disability determination process have also been made [14]. VBA also provides an annual report that summarizes the benefits used by veterans and their dependents [15]. The recent Post-9/11 GI bill provides assistance for tuition, housing allowances, and educational expenses for the veteran or family member [16]. Finally, in response to the need for more complete information, VBA is implementing VETSNET (Veterans Services Network), a new corporate database that replaces the legacy C\&P Benefits Delivery Network, which includes the C\&P Mini-Master file. 


\section{CONCLUSIONS}

Compensation and medical care are the two most important benefits VA offers to veterans with service-connected disability. These benefits are important because they provide lifetime financial support and medical care to veterans who have experienced major limb loss. Veterans with 50 percent or greater service-connected disability are eligible for a comprehensive medical benefits package at little or no cost but may seek medical care from other sources, including DOD and civilian providers. Select benefits also extend to the spouse and dependent children, even after the death of the veteran. In addition, other governmental agencies and organizations serve veterans with major limb loss (Appendix 3, available online only).

\section{ACKNOWLEDGMENTS}

\section{Author Contributions:}

Study concept and design: C. Maynard, L. V. McFarland, G. E. Reiber. Acquisition of data: C. Maynard.

Analysis and interpretation of data: C. Maynard.

Drafting of manuscript: C. Maynard, B. Flohr, T. A. Guagliardo, C. H. Martin, L. V. McFarland, J. D. Pruden, G. E. Reiber.

Critical revision of manuscript for important intellectual content:

C. Maynard, B. Flohr, T. A. Guagliardo, C. H. Martin, L. V. McFarland, J. D. Pruden, G. E. Reiber.

Statistical analysis: C. Maynard.

Obtained funding: G. E. Reiber.

Study supervision: G. E. Reiber.

Financial Disclosures: The authors have declared that no competing interests exist.

Funding/Support: This material was based on work supported by the VA Health Services Research and Development Service (grant IIR 05244) and the Career Scientist Award to Dr. Reiber (grant RCS 98-353). The views expressed in this article are those of the authors and do not necessarily reflect the position or policy of the VA or the DOD.

\section{REFERENCES}

1. Gross ML. Why treat the wounded? Warrior care, military salvage, and national health. Am J Bioeth. 2008;8(2):3-12. [PMID: 18570066]

DOI:10.1080/15265160802014977

2. Federal benefits for veterans and dependents [Internet]. Washington (DC): Department of Veterans Affairs. 2008 [cited 2008 Aug 4]. Available from: http://www1.va.gov/ opa/vadocs/fedben.pdf/.
3. Baker RR. Benefits for veterans: A historical context and overview of the current situation. In: Ainspan ND, Penk WE, editors. Returning wars' wounded, injured, and ill. Westport (CT): Praeger Security International; 2008. p. 1-12.

4. Rosenheck R, Frisman L, Sindelar J. Disability compensation and work among veterans with psychiatric and nonpsychiatric impairments. Psychiatr Serv. 1995;46(4):359-65. [PMID: 7788457]

5. Murdoch M, Hodges J, Cowper D, Sayer N. Regional variation and other correlates of Department of Veterans Affairs Disability Awards for patients with posttraumatic stress disorder. Med Care. 2005;43(2):112-21. [PMID: 15655424] DOI:10.1097/00005650-200502000-00004

6. Greenberg GA, Rosenheck RA. Compensation of veterans with psychiatric or substance abuse disorders and employment and earnings. Mil Med. 2007;172(2):162-68.

[PMID: 17357771]

7. Dobie DJ, Maynard C, Kivlahan DR, Johnson KM, Simpson T, David AC, Bradley K. Posttraumatic stress disorder screening status is associated with increased VA medical and surgical utilization in women. J Gen Intern Med. 2006;21 Suppl 3:S58-64. [PMID: 16637948] DOI:10.1111/j.1525-1497.2006.00376.x

8. Reiber GE, McFarland LV, Hubbard S, Maynard C, Blough DK, Gambel JM, Smith DG. Servicemembers and veterans with major traumatic limb loss from Vietnam war and OIF/ OEF conflicts: Survey methods, participants, and summary findings. J Rehabil Res Dev. 2010;47(4):275-98.

9. Friedman MJ. Posttraumatic stress disorder: An overview [Internet]. Washington (DC): Department of Veterans Affairs, National Center for Posttraumatic Stress Disorder, Fact Sheet. [cited 2008 Aug 5]. Available from:

http://www.ptsd.va.gov/public/pages/fslist-ptsd-overview.asp/.

10. Terrio H, Brenner LA, Ivins BJ, Cho JM, Helmick K, Schwab K, Scally K, Bretthauer R, Warden D. Traumatic brain injury screening: Preliminary findings in a US Army Brigade Combat Team. J Head Trauma Rehabil. 2009;24(1):14-23. [PMID: 19158592]

DOI:10.1097/HTR.0b013e31819581d8

11. Boehmer TK, Flanders WD, McGeehin MA, Boyle C, Barrett DH. Postservice mortality in Vietnam veterans: 30-year follow-up. Arch Intern Med. 2004;164(17):1908-16.

[PMID: 15451767]

DOI:10.1001/archinte.164.17.1908

12. Weeks WB, Mills PD, Waldron J, Brown SH, Speroff T, Coulson LR. A model for improving the quality and timeliness of compensation and pension examinations in VA facilities. J Healthc Manag. 2003;48(4):252-62.

[PMID: 12908225]

13. 2009 Monday morning workload reports [Internet]. Washington (DC): Veterans Benefits Administration; 2009. Available from: http://www.vba.va.gov/REPORTS/mmwr/ historical/2009/index.asp/. 
JRRD, Volume 47, Number 4, 2010

14. Committee on medical evaluation of veterans for disability compensation; McGeary M, Ford MA, McCutchen SR, Barnes DK, editors. A 21st century system for evaluating veterans for disability benefits. Washington (DC): National Academies Press; 2007.

15. Veterans Benefits Administration. Annual benefits report fiscal year 2007 [Internet]. Washington (DC): Department of Veterans Affairs; 2007. Available from:

http://www.vba.va.gov/REPORTS/abr/2007 abr.pdf/.
16. The Post-9/11 GI Bill [Internet]. Washington (DC): Department of Veterans Affairs [updated 2009 Nov 6; cited 2009 May 22]. Available from: http://www.gibill.va.gov/GI_Bill_Info/ benefits.htm/.

Submitted for publication February 17, 2009. Accepted in revised form August 5, 2009. 